\title{
Delayed bipedicled flap: An alternative and new method for reconstruction of distal leg defect after gunshot trauma: A case report and review of the literature
}

\author{
Ali Rıza Yıldırım, M.D., Murat İğde, M.D., Mehmet Onur Öztürk, M.D., \\ Hasan Murat Ergani, M.D., Ramazan Erkin Ünlü, M.D.
}

Department of Plastic Surgery, Ankara Numune Training and Research Hospital, Ankara-Turkey

\begin{abstract}
Shotgun injury is a trauma that leads to soft tissue defects, in which important structures such as the tendon and bone are exposed with fractures in the distal lower extremity. Because this region has insufficient soft tissue support, local flap options are highly limited. Although the most suitable options are free or perforator flaps for contemporarily reconstructing that region; owing to such highenergy traumas, the available local flaps are becoming more suitable. Besides having various advantages, bipedicled flaps are commonly used for reconstructing small- and medium-sized lower extremity defects. This study aimed to discuss the use of a delayed bipedicled flap, which has not been previously described in the literature.
\end{abstract}

Keywords: Bipedicled flap; distal leg; gunshot trauma; surgical delay.

\section{INTRODUCTION}

Closure of complex skin and soft tissue defects in the distal leg, which result from shotgun injuries, is quite difficult for reconstructive surgery. High-energy injuries in that region frequently result in soft tissue defects with significant structures such as tendon and bone and open tibia fractures being exposed. Because open tibia fractures have high malunion and infection incidences, urgent irrigation and debridement of devitalized soft tissues and bone fragments are required. ${ }^{[1,2]}$

The reconstruction of open tibia fracture accompanied by bone and soft tissue defects is difficult because such regions have poor circulation and insufficient local surplus skin, ${ }^{[3]}$ making reconstruction options limited. For the reconstruction of

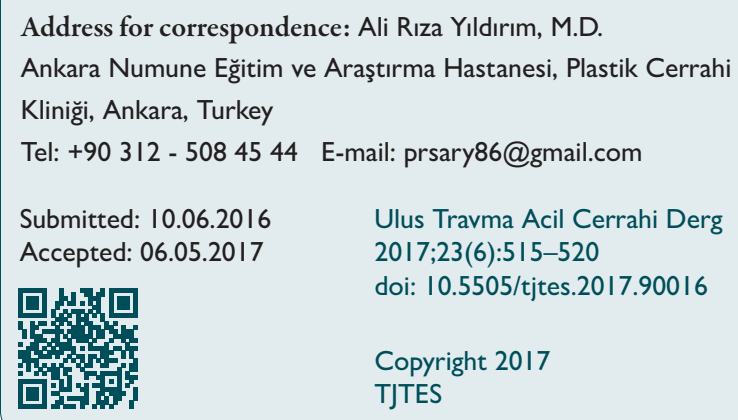

these defects, various local fasciocutaneous muscle flap and free flap options are available. Because of short operation duration, not involving multiple surgical areas, and low cost, local flaps are simple and favorable. In addition, local flaps can be alternatively used in older patients with comorbidities for whom free flaps are not suitable. ${ }^{[4]}$

Among these local flap options, bipedicled flaps provide sufficient tissue for small- and medium-sized defects, have a constant circulation, are easy and rapid to harvest, and have reasonable donor site morbidity. ${ }^{[5]}$

In this study, existing literature was reviewed with regard to the outcomes of patient who underwent reconstruction by delayed bipedicled flap, which has not been previously described in the literature and is designed differently from classic bipedicled flaps, and the use of that flap in distal leg soft tissue defects was discussed.

\section{CASE REPORT}

A 17-year-old male patient sustained a shotgun injury from an approximate distance of $3 \mathrm{~mm}$, which resulted in an exposed tibia defect that measured $8 \times 4 \mathrm{~cm}$ and $3 \mathrm{~cm}$ deep on the anterior tibial compartment of right distal third of the leg (Fig. la). At another medical center, because of the fracture in the distal third of the tibia and fibula, bone stabilization was performed via external fixator. Because the wound was not clean, 

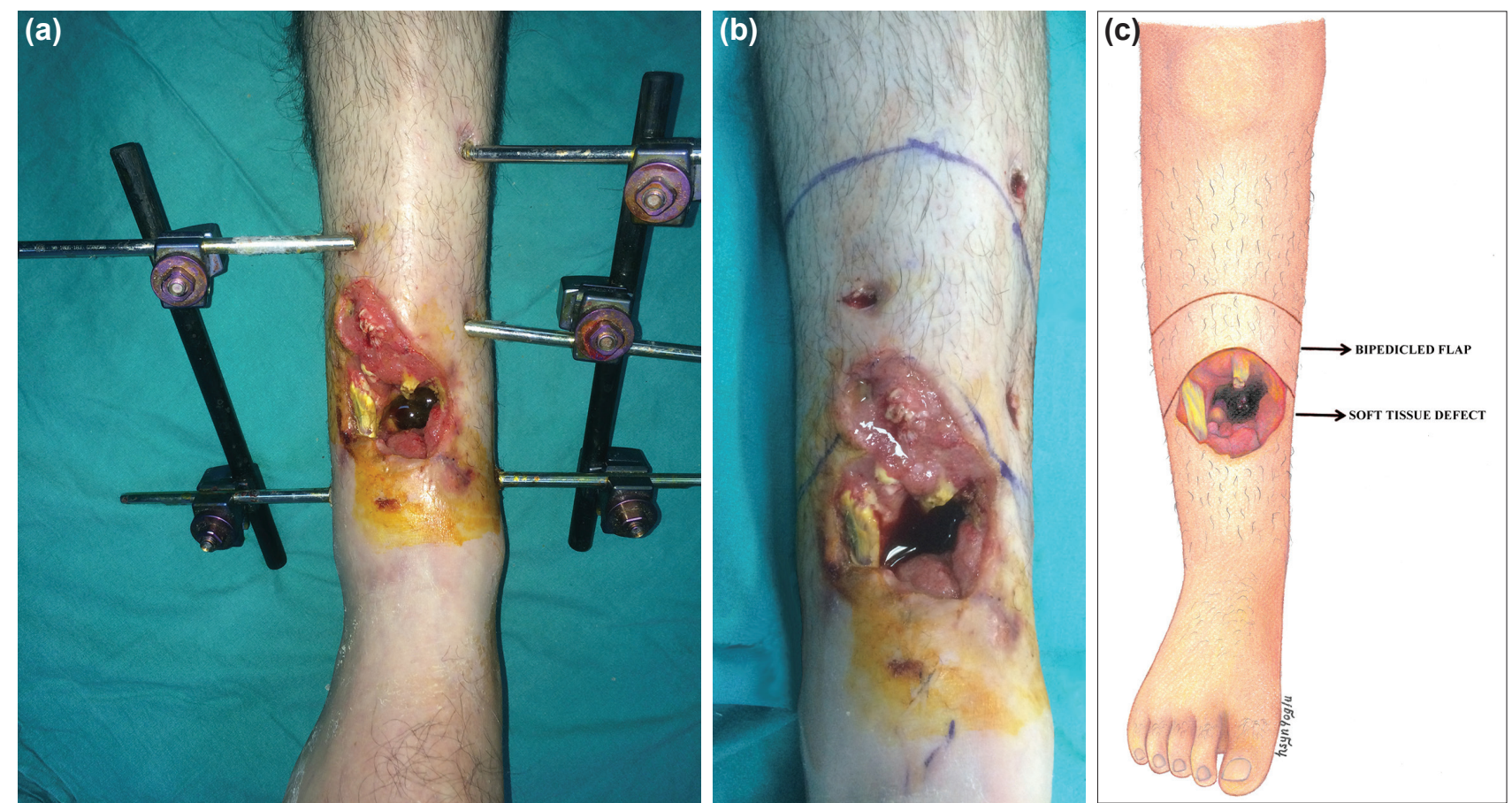

Figure 1. (a) As a result of the shotgun injury, an exposed tibia defect measuring $8 \times 4 \mathrm{~cm}$ dimensions and $3 \mathrm{~cm}$ deep on the anterior tibial compartment of the right distal third of the leg. Planning the flap width to be approximately half of the present defect length, with a 3:1 ratio and $12 \times 4 \mathrm{~cm}$ dimensions on the transverse axis. (b) Preoperative view of the flap. (c) Illustration of the flap.

the existing defect was treated with debridement and two sessions of vacuum-assisted closure therapy. Furthermore, following wound culture, wide-spectrum antibiotics therapy was initiated. To evaluate potential vascular injuries, angiography was performed, and anterior tibial artery and peroneal artery injuries were detected. Because two major arteries were injured and the injury zone was wide, reconstruction was primarily planned using local flaps instead of free flaps. At the end of a 2-week follow-up period that involved debridement and dressing procedures, wound culture revealed that the wound was clean. Then, reconstruction with two-stagedelayed bipedicled flaps was planned.
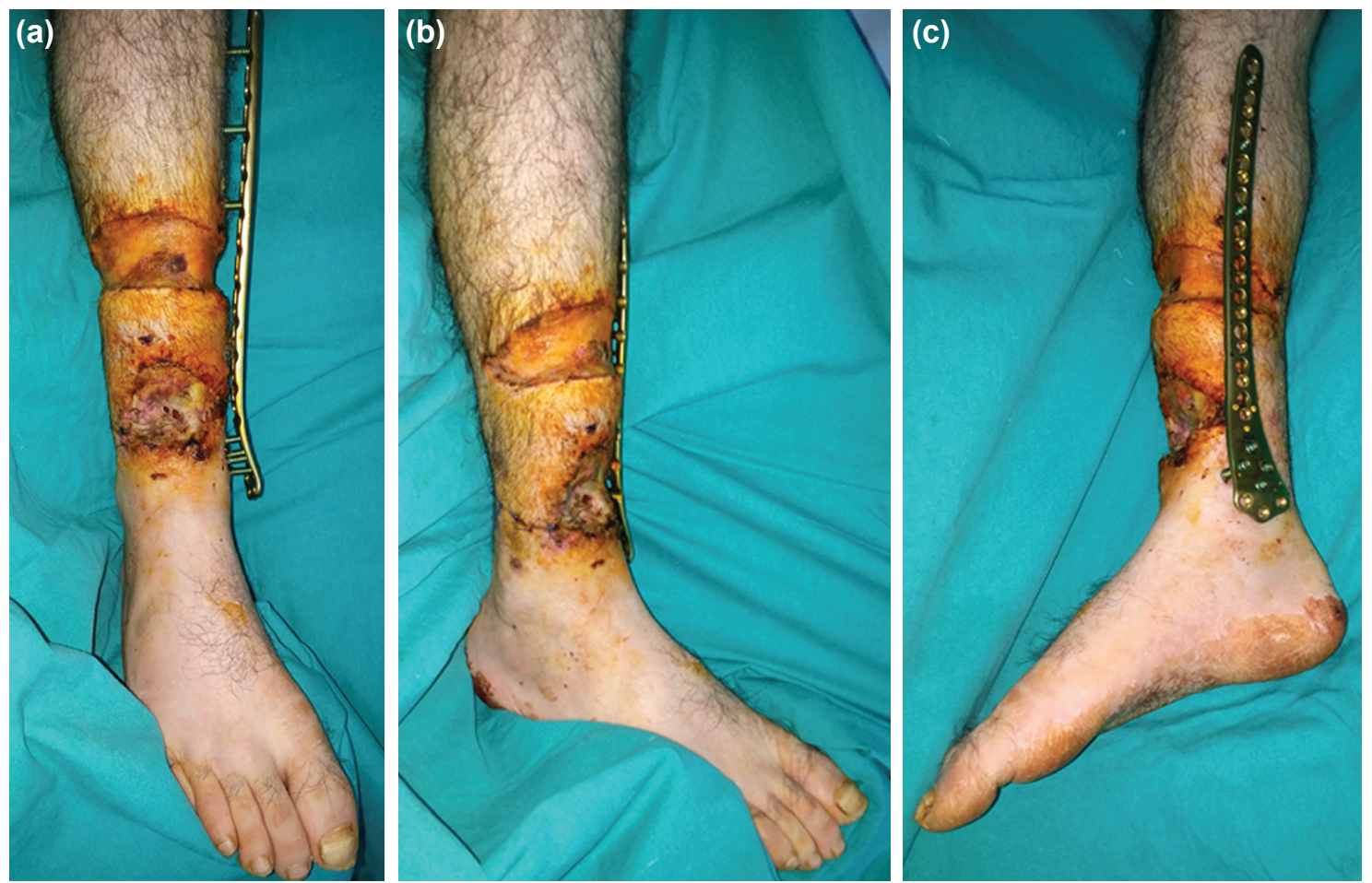

Figure 2. (a-c) First early postoperative view (anterior, lateral, and medial views, respectively). 

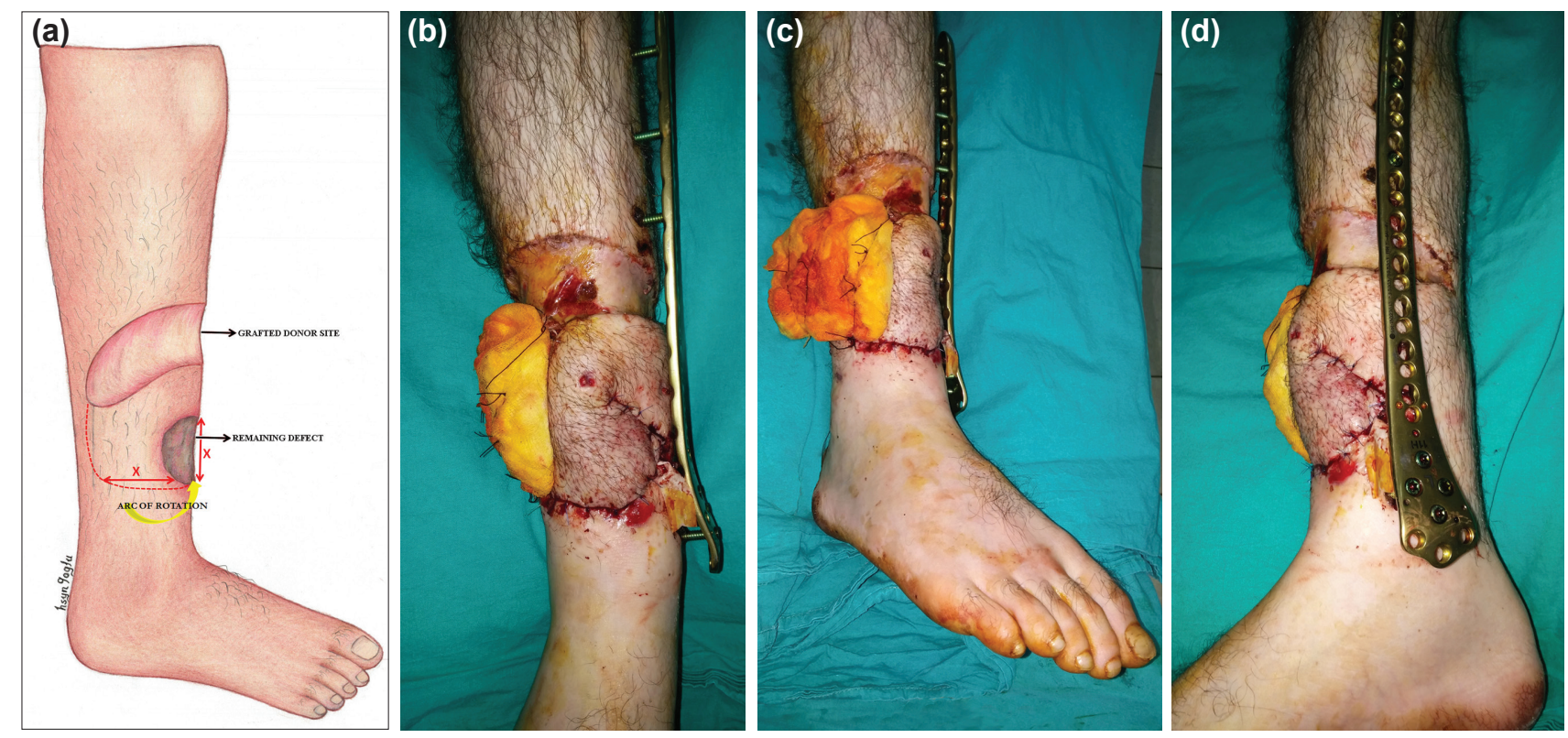

Figure 3. (a) Illustration of the flap. Two weeks after the first operation, rendering the flap single pedicled by cutting from the lateral and inferior sides of the delay procedure applied flap with respect to the remaining defect area and closure of the defect by rotation. In the secondary operation, flap division must be performed with approximately " $x$ " units lateral, if vertical axis of the remaining defect is regarded as " $x$ " units. (b-d) First early second postoperative view (anterior, lateral, and medial views, respectively).

Under general anesthesia, after surgical debridement, the existing external fixator was removed and implanted in the medial side. Then, the width of the flap was planned to be approximately half of the present defect length, with a 3:1 ratio on the transverse axis (Fig. Ib, c). The flap was preferred on the transverse axis instead of the longitudinal axis because of the following two reasons. First, the bipedicled flap planned for the longitudinal axis would be insufficient for the closure of such a wide defect. Second, the flap would not be able to close the dead space because the defect had a deep pouch. Subsequently, the flap was elevated in the subfascial plane and advanced without tension. The donor site and remaining defect were reconstructed using a splitthickness skin graft till the second stage for biologic dressing (Fig. 2a-c). After 2 weeks, the bipedicled flap was transformed to a single pedicle flap by cutting from the lateral side at the length of the remaining defect site and $3 \times 2 \mathrm{~cm}$ end part of the flap was disepithelialized for pouch closure

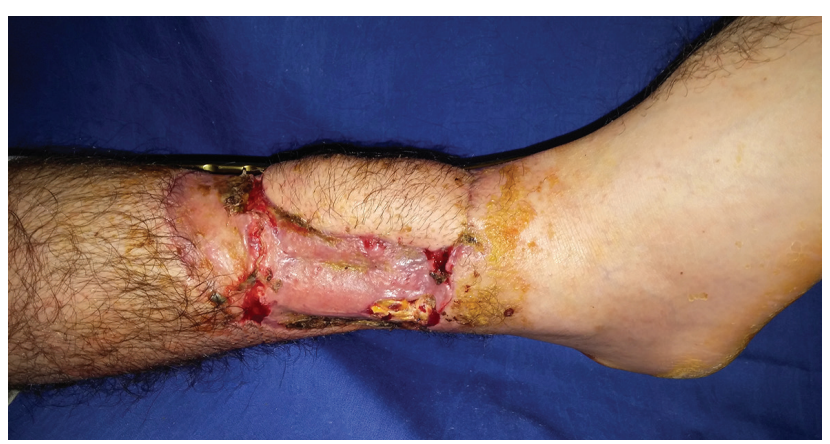

Figure 4. The lateral view of the flap in the first month of the postoperative follow-up. No major problem was encountered, except for the unhealed partial skin graft area. and the flap was adapted to the defect by rotation (Fig. 3ad). The donor site was reconstructed using a split-thickness skin graft. In postoperative care, leg elevation and I-week patient immobilization was provided. On the third day, the tie-over dressing was removed, and no major problem was encountered, except the unhealed partial skin graft area. In the postoperative period, venous congestion/flap necrosis was not observed. Unhealed partial graft zones in the donor site were observed as postoperative minor complications (Fig. 4). Complete recovery was achieved by minor debridement and dressing. The flap was controlled at I, 3, and 6 months after surgery (Fig. 5a-c).

\section{DISCUSSION}

Reconstruction of open tibia fracture with exposed bone and tendon accompanied by defects in the distal third of the leg is quite problematic for reconstructive surgery. Because local flap options are limited for the reconstruction of that region, closure of the current defect is a tough procedure.

Shotgun injury is a complex distal leg defect. The management of defects that occur because of such injuries involves a three-step algorithm that comprises urgent care, early damage control, and late reconstruction steps. The first step includes bleeding control, systematic antibiotics therapy, and infection control by serial debridement; in contrast, the last step involves bone fixation and closure of the defect by soft tissues. ${ }^{[6]}$ Moreover, such injuries can be frequently associated with major fractures (48\%), impairment of soft tissue integrity (59\%), vascular injuries (35\%), and nerve damage. ${ }^{[7]}$ 

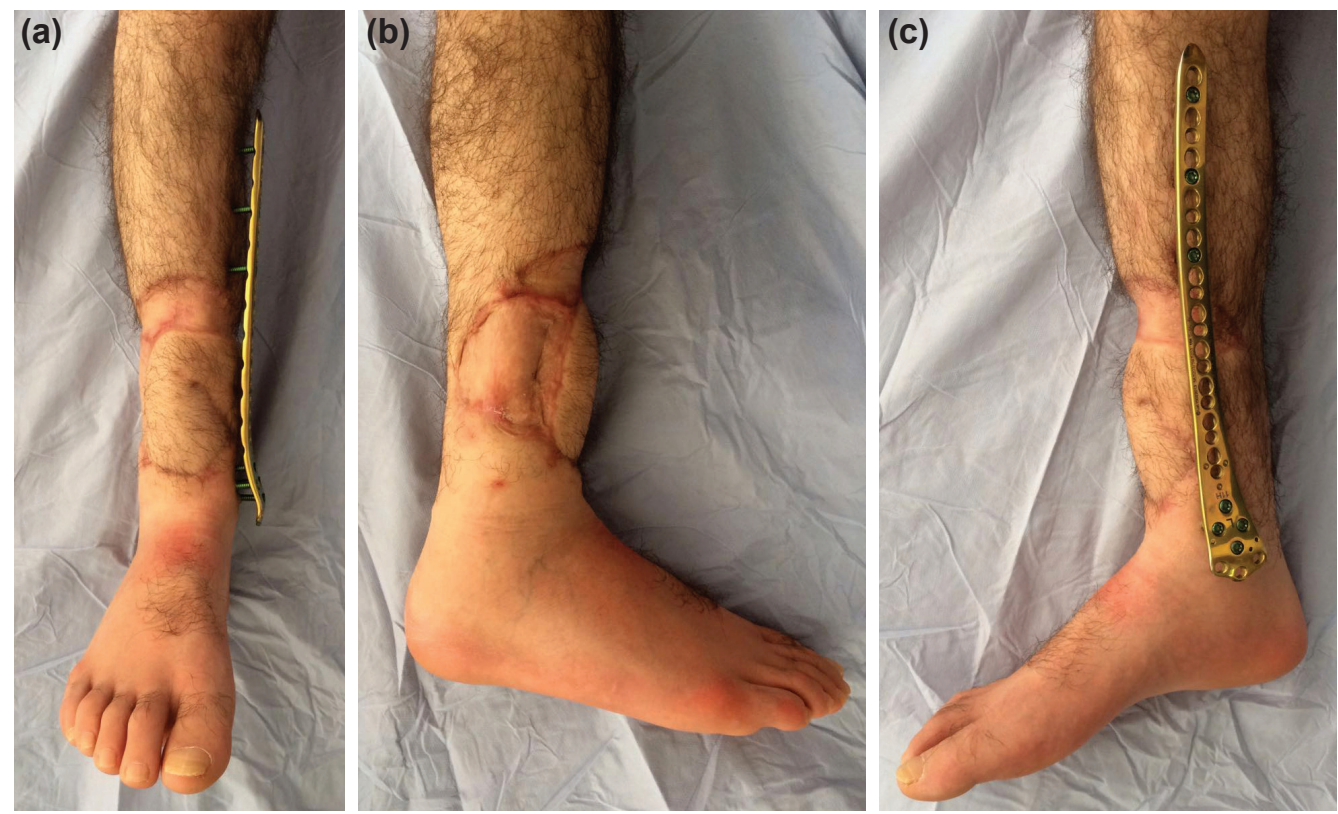

Figure 5. (a-c) The view of the flap in the third month of postoperative follow-up.

Therefore, controlling defects that result from shotgun injuries using preferred antibiotic therapy and serial debridement owing to over contamination and preparing the wound for reconstruction is crucial. Patient should also be simultaneously evaluated in detail for secondary bone, tendon, and nerve injuries to shotgun injuries.

Free flaps have been lately preferred for the closure of the distal third of leg defects with soft tissues. ${ }^{[8]}$ However, free flaps have various difficulties such as major artery sacrification, long operation duration, donor site morbidity, and requirement of microsurgery experience and equipments. ${ }^{[9]} \mathrm{Be}-$ cause shotgun injuries are accompanied by significant vessel injuries, the use of free flaps is limited. In our case, because both the anterior tibial artery and posterior tibial (PT) injury was present, free flap reconstruction was not preferred.

Nowadays, reverse flow sural flaps, local fasciocutaneous flaps, perforator flaps, and bipedicled flaps are used for reconstructing that region. ${ }^{[9-13]}$ Reverse flow sural flaps are indicated for reconstructing distal leg, foot ankle, and heel defects. The flap is advantageous because of being one step, being rapidly and easily dissected, short operation duration, and relatively bloodless surgery. Damage of the peroneal artery and perforators is contraindicated under conditions such as venous insufficiency and absence of the saphenous vein. ${ }^{[8]}$ In such cases, owing to peroneal artery injury as a result of shotgun injury, reconstruction with reverse flow sural flaps was not performed.

In the study conducted by Parrett et al., ${ }^{[14]}$ a classification was developed according to arteries being intact or not for the reconstruction of defects in the pretibial region of the distal leg. With respect to this classification, for patients with an open
PT artery, posterior tibial artery perforator flaps and medial plantar artery flaps are suggested. PT pedicled perforator flap is the most suitable option for anterior (pretibial) or medial distal leg defects. Although flaps are suggested for small- and medium-sized defects, it can feed up to $19 \times 13 \mathrm{~cm}$ skin island over single perforator. ${ }^{[15]}$ The PT pedicled perforator flap is advantageous because it does not sacrifice the muscle and major artery, requires microvascular anastomose, provides sufficient soft tissue support, and supports reconstruction with similar tissues. ${ }^{[16]}$

In propeller flaps, because of pedicle bending, torsion partial/ total flap failure or venous problems can be observed. ${ }^{[17]}$ Bekara et al. ${ }^{[18]}$ compared pedicled perforator flaps with free flaps in the reconstruction of the lower extremity and observed similar complications with both flaps. For the reconstruction of dorsal leg defects, the most appropriate flap was suggested to have a low donor site morbidity and for which the surgeon is more experienced.

Although local flaps have a higher complication rate, they are more frequently preferred because they do not require microsurgery and are simpler. ${ }^{[19]}$ Bipedicled flaps provide successful reconstruction by being used in various anatomical regions. Bipedicled flaps were first defined in 1957 by Crawford ${ }^{[20]}$ and named "double-pedicled;" they are presented as an alternative to tube and cross-leg flaps. ${ }^{[2]]}$

Because of their various advantages, bipedicled flaps are used in the reconstruction of the lower extremity. Major advantages include the flap being easier compared with microsurgery techniques, having a safe circulation, minimum donor site morbidity, and less postoperative monitorization need. It is also important for the reconstruction to be performed 
using a similar tissue. In a study, for tibia or implant exposed defects, bipedicled fasciocutaneous flaps were very useful as closing with similar tissue in such defects. ${ }^{[22]}$

Makhlouf et al. ${ }^{[5]}$ suggested that during bipedicled flap-raising processes, axial cutaneous perforators were preserved by longitudinal incision. Nevertheless, Hallock ${ }^{[27]}$ and Schwabegger ${ }^{[28]}$ reported that viability was not influenced unless the width: height ratio of bipedicled fasciocutaneous flaps exceed 4:1.[21]

In previous studies, bipedicled flaps were useful in lower extremity reconstructions, in limited use and small dimension $(<2.5 \mathrm{~cm})$ defects. ${ }^{[25]}$ However, the use of classic bipedicled flaps for the reconstruction of defects having a deep pouch and wide dimension is not appropriate.

In our case because the defect was wide and had a deep pouch, reconstruction with classic bipedicled flaps did not appear to be possible. The closure without tension and closure of dead space were not possible because the defect radius was large and the pouch was deep, respectively. Hence, the flap was designed as a two-stage bipedicled one on the transverse axis, and after the first session, during circulation monitoring, no problem was observed. Then, by employing the surgical delay procedure, reconstruction was completed. Surgical delay procedure was first used by Gillies ${ }^{[26]}$ in 1920 for tube flaps to increase the living zones of the flap and necrosis of the distal part. ${ }^{[2]}$ The procedure is obtained by partially interrupting the normal blood flow without changing the flap position. ${ }^{[28]} \mathrm{A}$ study revealed that the appropriate time required for flap transfer was 2 weeks. ${ }^{[29]}$ In the present case, after a 2-week surgical delay, the flap was rendered single pedicled and adapted to the defected area by rotation. During postoperative follow-up, no arterial or venous problem was observed.

In conclusion, high-energy injuries in the distal leg, such as shotgun injuries, can result in soft tissue defects accompanied with bone fractures in which major arteries are damaged. While evaluating the ideal options for the reconstruction of such defects, the accompanying artery, muscle, bone injuries, patient's performance, comorbidities, and potential wound infection should be considered. Newly introduced delayed bipedicled flaps should be considered as alternative options for the reconstruction of these defects.

\section{Conflict of interest: None declared.}

\section{REFERENCES}

1. Khatod M, Botte MJ, Hoyt DB, Meyer RS, Smith JM, Akeson WH. Outcomes in open tibia fractures: relationship between delay in treatment and infection. J Trauma 2003;55:949-54. [CrossRef]

2. Dickson K, Katzman S, Delgado E, Contreras D. Delayed unions and nonunions of open tibial fractures. Correlation with arteriography results. Clin Orthop Relat Res 1994:189-93.
3. Salibian AH, Menick FJ. Bipedicle gastrocnemius musculocutaneous flap for defects of the distal one-third of the leg. Plast Reconstr Surg 1982;70:17-23. [CrossRef]

4. Parrett BM, Winograd JM, Lin SJ, Borud LJ, Taghinia A, Lee BT. The posterior tibial artery perforator flap: an alternative to free-flap closure in the comorbid patient. J Reconstr Microsurg 2009;25:105-9. [CrossRef]

5. Makhlouf MV, Obermeyer Z. Bipedicle flap for wounds following achilles tendon repair. Plast Reconstr Surg 2008;121:235e-6e. [CrossRef]

6. Penn-Barwell JG, Brown KV, Fries CA. High velocity gunshot injuries to the extremities: management on and off the battlefield. Curr Rev Musculoskelet Med 2015;8:312-7. [CrossRef]

7. Acartürk TO. Reconstruction of lower extremity close-range shotgun injuries with gracilis free flap: a report of two cases. Ulus Travma Acil Cerrahi Derg 2010;16:367-70.

8. Parrett BM, Matros E, Pribaz JJ, Orgill DP. Lower extremity trauma: trends in the management of soft-tissue reconstruction of open tibiafibula fractures. Plast Reconstr Surg 2006;117:1315-22. [CrossRef]

9. Eser C, Kesiktaş E, Gencel E, Aslaner EE, Yavuz M. An alternative method to free flap for distal leg and foot defects due to electrical burn injury: distally based cross-leg sural flap. Ulus Travma Acil Cerrahi Derg 2016;22:46-51.

10. Almeida MF, da Costa PR, Okawa RY. Reverse-flow island sural flap. Plast Reconstr Surg 2002;109:583-91. [CrossRef]

11. Raveendran SS, Perera D, Happuharachchi T, Yoganathan V. Superficial sural artery flap-a study in 40 cases. Br J Plast Surg 2004;57:266-9.

12. Kamath BJ, Joshua TV, Pramod S. Perforator based flap coverage from the anterior and lateral compartment of the leg for medium sized traumatic pretibial soft tissue defects-a simple solution for a complex problem. J Plast Reconstr Aesthet Surg 2006;59:515-20. [CrossRef]

13. Granzow JW, Li A, Suliman A, Caton A, Goldberg M, Boyd JB. Bipedicled flaps in posttraumatic lower-extremity reconstruction.J Plast Reconstr Aesthet Surg 2013;66:1415-20. [CrossRef]

14. Parrett BM, Talbot SG, Pribaz JJ, Lee BT. A review of local and regional flaps for distal leg reconstruction.J Reconstr Microsurg 2009;25:445-55.

15. Koshima I, Ozaki T, Gonda K, Okazaki M, Asato H. Posterior tibial adiposal flap for repair of wide, full-thickness defect of the Achilles tendon.J Reconstr Microsurg 2005;21:551-4. [CrossRef]

16. Geddes CR, Morris SF, Neligan PC. Perforator flaps: evolution, classification, and applications. Ann Plast Surg 2003;50:90-9. [CrossRef]

17. Gir P, Cheng A, Oni G, Mojallal A, Saint-Cyr M. Pedicled-perforator (propeller) flaps in lower extremity defects: a systematic review. J Reconstr Microsurg 2012;28:595-601. [CrossRef]

18. Bekara F, Herlin C, Somda S, de Runz A, Grolleau JL, Chaput B. Free versus perforator-pedicled propeller flaps in lower extremity reconstruction: What is the safest coverage? A meta-analysis. Microsurgery 2016 Mar 28 [Epub ahead of print], doi:10.1002/micr.30047. [CrossRef]

19. Quaba O, Quaba A. Pedicled perforator flaps for the lower limb. Semin Plast Surg 2006;20:103-11. [CrossRef]

20. Crawford BS. The repair of defects of the lower limb, using a local flap. Br J Plast Surg 1957;10:32-5. [CrossRef]

21. Dujon DG, Khan UD, Aslam S. Bipedicle flaps: simple solutions for difficult problems in the extremities. Br J Plast Surg 1997;50:641-5.

22. Darwish AM. Bipedicled flap in reconstruction of exposed tibia. J Plast Reconstr Aesthet Surg 2010;63:160-3. [CrossRef]

23. Hallock GG. Bipedicled fasciocutaneous flaps in the lower extremity. Ann Plast Surg 1992;29:397-401. [CrossRef]

24. Schwabegger A, Ninković M, Wechselberger G, Anderl H. The bipedicled flap on the lower leg, a valuable old method? Its indications and limitations in 12 cases. Scand J Plast Reconstr Surg Hand Surg 1996;30:187-93. [CrossRef]

25. Oudit D, Tillo O, McCoubrey G, Crawford L, Juma A. A simplified technique of using bipedicled fasciocutaneous flaps in closure of soft tissue defects of the anterior leg in patients with fasciotomy wounds. J Trauma 
2007;63:1185-6. [CrossRef]

26. Gillies HD. The tubed pedicle in plastic surgery. NYJ Med 1920;111:1.

27. Ghali S, Butler PE, Tepper OM, Gurtner GC. Vascular delay revisited.

Plast Reconstr Surg 2007;119:1735-44. [CrossRef]
28. Grabb WC, Smith JW, Aston SJ, Beasley RW, Thorne C. Grabb and Smith's plastic surgery. 6th ed. Philadelphia: Lippicott-Raven; 2007.

29. Milton SH. The effects of "delay" on the survival of experimental pedicled skin flaps. Br J Plast Surg 1969;22:244-52. [CrossRef]

\section{OLGU SUNUMU - ÖZET}

\section{Gecikmeli bipediküllü flep: Ateşli silah yaralanması sonrası bacak distalindeki defektlerin} rekonstrüksiyonu için alternatif ve yeni metod: Olgu sunumu ve literatürün taranması Dr. Ali Rıza Yıldırım, Dr. Murat İğde, Dr. Mehmet Onur Öztürk, Dr. Hasan Murat Ergani, Dr. Ramazan Erkin Ünlü

Ankara Numune Eğitim ve Araştırma Hastanesi, Plastik Cerrahi Kliniği, Ankara

Ateşli silah yaralanmaları, bacak distal bölgesinde kırık eşlik eden kemik, tendon gibi önemli yapıların ekspoze olduğu yumuşak doku defektlerine yol açan travmalardan biridir. Bu bölgenin yeterli yumuşak doku desteğine sahip olmaması nedeniyle lokal flep seçenekleri oldukça sınırlıdır. Günümüzde bu bölgenin rekonstrüksiyonu için en uygun seçenekler serbest flepler ve perforator flepler olmasına rağmen bu tür yüksek enerjili travmalar nedeniyle mevcut lokal flepler daha uygun hale gelmektedir. Bipediküllü flepler, çok çeşitli avantajları olması sebebiyle küçük ve orta boyutlu alt ekstremite defeklerinin rekonstrüksiyonunda sıkça kullanılmaktadır. Bu çalışmanın amacı, bacak distalindeki geniş yumuşak doku defektlerinin rekonstrüksiyonu için daha önce literatürde tanımlanmayan gecikmeli bipediküllü flebin kullanımı ve hasta sonuçları üzerinden mevcut literatür gözden geçirilerek flebin kullanımı tartışıldı.

Anahtar sözcükler: Ateşli silah yaralanması; bacak distali; bipediküllü flep; cerrahi geciktirme.

Ulus Travma Acil Cerrahi Derg 2017;23(6):5I5-520 doi: 10.5505/tjtes.2017.900।6 